\title{
National Insularity and the Reception of Shakespeare
}

\section{Werner Habicht}

\section{(2) OpenEdition}

\section{Journals}

\section{Electronic version}

URL: http://journals.openedition.org/shakespeare/1277

DOI: 10.4000/shakespeare.1277

ISSN: 2271-6424

\section{Publisher}

Société Française Shakespeare

\section{Printed version}

Date of publication: 1 November 1994

Number of pages: 141-148

\section{Electronic reference}

Werner Habicht, "National Insularity and the Reception of Shakespeare », Actes des congrès de la Société française Shakespeare [Online], 12 | 1994, Online since 01 January 2007, connection on 02 May 2019. URL : http://journals.openedition.org/shakespeare/1277 ; DOI : 10.4000/shakespeare.1277 
COSMOPOLITISME ET INSULARITÉ 


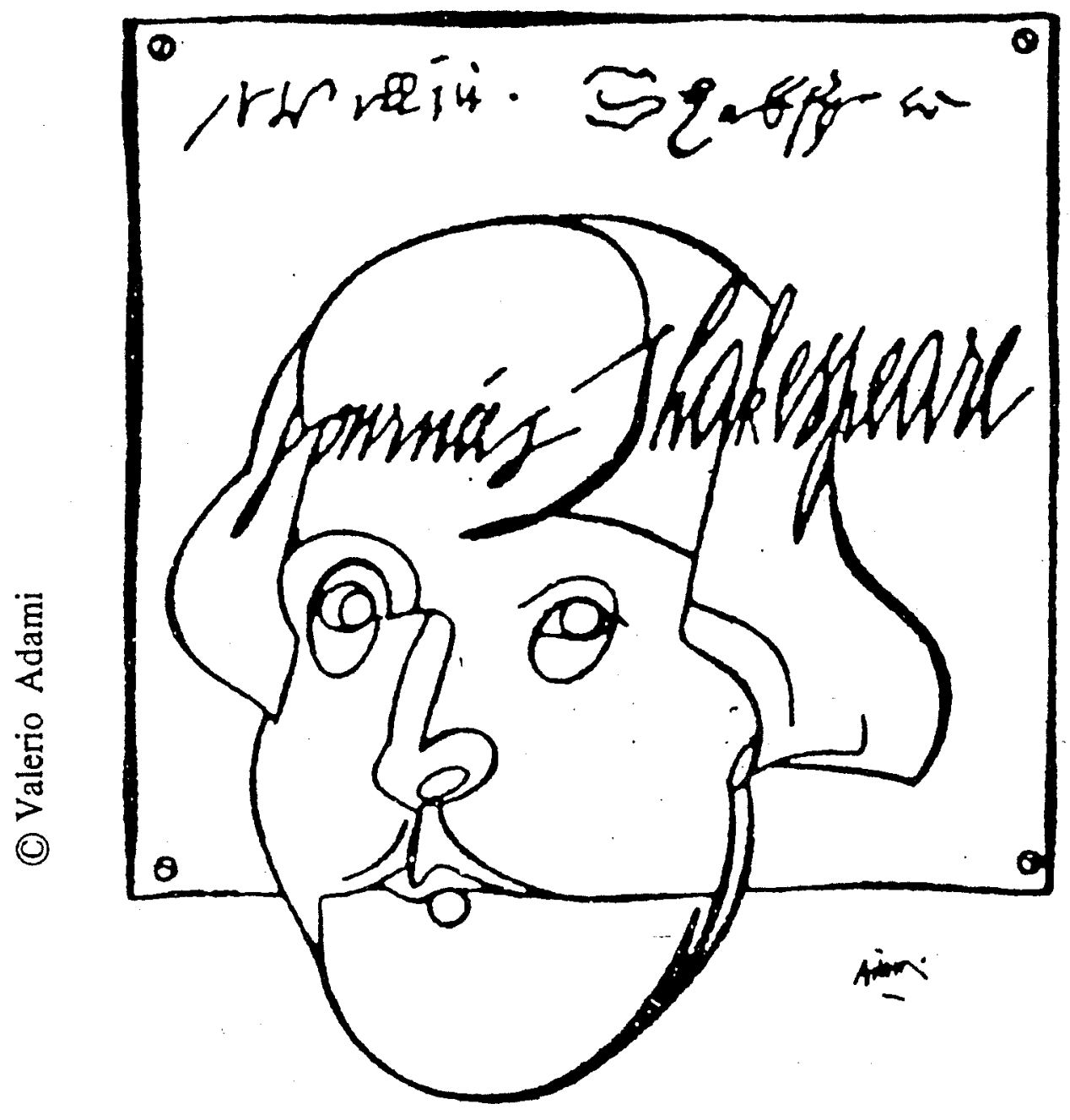

Affiche de Valerio Adami, spécialement conçue pour les journées Shakespeare 1979 


\section{SHAKESPEARE}

COSMOPOLITISME ET INSULARITÉ

Société Française Shakespeare

Actes du Congrès 1993

sous la direction

de

M. T. JONES-DAVIES

Ouvrage publié avec le soutien de

BARCLAYS

BARCLAYS BANK S.A

PARIS

LES BELLES LETTRES

1994 
Tous droits de traduction, de reproduction et d'adaptation réservés pour tous les pays.

(C) 1994 Société d'édition Les Belles Lettres, 95 bd Raspail 75006 Paris

ISBN 2.251.69122-7 


\section{National insularity and the reception of Shakespeare*}

In a metaphorical sense, insularity appears to have characterized the way Shakespeare was discovered and appropriated in various countries which, geographically speaking, are solidly continental. Admiration bestowed upon the British dramatist's work has been made part of quests for national theaters, national literatures, national cultures and national identities. Even in developing countries in to-day's world there are occasionally suggestions to that effect. In Europe Shakespeare was embraced - with varying degrees of intensity - while national consciousnesses were in the process of being defined or redefined in the eighteenth and nineteenth centuries. And yet the impression that Shakespeare's transposition to non-English cultures contributed to producing new forms of national insularity is only one part of the truth. The other part reveals itself once one is ready to consider the intricate contexts of such processes, and also the potential for supranational interaction contained in them.

By way of illustration a brief reconsideration of what happened in Germany may be attempted, if only to suggest that notions about "Shakespeare in Germany" and "Unser Shakespeare" deserve a revision. Not surprisingly, nationalist discourse with regard to Shakespeare reached its most striking phase in the imperial period between 1870 and 1918, with a kind of apex occurring around 1900. It was during that time that the story of Shakespeare's German discovery emerged as a national myth, for which Gundolf's cult book Shakespeare und der deutsche Geist (1911) provided a theoretical superstructure. It was also at that time that the first metrical translation of Shakespeare's plays, begun a hundred years earlier by A. W. Schlegel and completed in 1832 under the guidance of Ludwig Tieck, was deemed unsurpassable in quality. At least this is what, in 1901, Professor Brandl, then

* Abbreviated text of a paper delivered at the 1993 congrès of the Sociéte française Shakespeare. 
president of the German Shakespeare Gesellschaft, declared officially, after having consulted leading authors, translators and theatre directors on the subject. These all more or less shared the view of the poet and dramatist Ludwig Fulda, who noted that «the Schlegel-Tieck Shakespeare has become our Shakespeare [unser Shakespeare], a German poet, who is as close to us as are our own classics» ${ }^{1}$. Hence, also around 1900, "unser Shakespeare" was verbally enthroned as the third German classic, alongside Schiller and Goethe. In 1904 he was also enthroned materially, in the shape of a monumental life-size statue created by the sculptor Otto Leesing (by marvellous coincidence a namesake of the alleged first literary proponent of the Bard) ; significantly the monument was erected in Weimar, at a point in the city park that commands a good view of Goethe's garden house. Shakespeare's status as a spiritual leader had already been asserted by Julius Langbehn, who in his Rembrandt der Erzieher (1890), another cult book of the time, had described him, along with the Dutch painter, as an idol for German conservative revolutionaries to look up to in their battle against materialism and cultural superficiality. At the same time statistics were made available to prove that German theatres performed Shakespeare more often than any other serious dramatist. The climax was registered in 1906, with 1653 performances of 28 different plays - more that could be dreamt of in England itself $^{2}$. Not even during the first world war did these numbers decrease significantly. Chancellor Berthmann-Hollweg, in a speech made in 1914, explicitly encouraged productions of the war enemy's poet, and his view was supported by the dramatist Gerhart Hauptmann, who in his notorious manifesto declared that although «[Shakespeare] was born and buried in England, it is in Germany that he truly lives» ${ }^{3}$. The nationalist insularity of such statements is quite obvious. Characteristically they were once again to be revived, and exploited for purposes of political propaganda, during the Third Reich.

But it is also true that such discourse was a temporarily narrowed-down version of what had originally been an irritatingly diversified and polemically debated cross-cultural involvement with Shakespearean drama. For example, the conviction of late nineteenth-century priests of the cult - that the eighteenth-century discovery of Shakespeare's merits was a predominantly German affair - was wrested mainly from shreds of evidence available in German sources. Accordingly, G. E. Lessing was in retrospect 
awarded the distinction of having been the first to recommend, in his 17. Literaturbrief (1759), Shakespeare as a paradigm more appropriate for the German theatre than what had been imposed on it by the tyranny of French classicism. J. G. Herder was praised for having discovered Shakespeare's roots in nordic popular poetry and for having sensed his consanguinity with the Germans. The Sturm und Drang dramatists inspired by him, including the young Goethe, were applauded for the alleged Shakespeareanism of their powerfully unrestrained plays. Romantics such as Friedrich and A. W. Schlegel were given credit for having achieved a second German Shakespeare discovery by exhibiting the autonomous, "organic" and indeed "romantic" quality of Shakespearean drama. And so on. In due course Shakespeare's shaping influence on virtually every major German dramatist from Kleist to Büchner and beyond, and on novelists and philosophers as well, was painstakingly recorded. One could have thought that, as Leo Tolstoy remarked sarcastically in 1907, «Shakespeare's fame originated in Germany, and thence was transferred to England $»^{4}$.

That this general picture, which was the basis of the German Shakespeare jingoism of the period around 1900 and which also crept into assessments of the history of German Literature, is a truncated and distorted one, has, of course, been demonstrated from the comparative angle - not only in Van Tieghem's third volume of Le Préromantisme (1947), but also with much further detail - in several more recent publications ${ }^{5}$. Even in the nineteenth century itself German scholars were perfectly capable of demonstrating that the great Lessing had by no means been the first to promote Shakespeare in Germany in defiance of French cultural hegemony ; that it was in fact via France that many Germans, including Lessing himself, had come to know about him - via the French translation of The Spectator, for instance ; that Lessing's own ideas had evolved from those of Voltaire, with whom he shared the limited knowledge of the same three or so Shakespearean plays ${ }^{6}$; and that he had also drawn on English critics from Dryden to Henry Home. The Sturm und Drang poets' potent belief in original genius and their concomitant Shakespeare enthusiasm was demonstrably derived from English sources such as Young and Macpherson, while the adverse criticism to which their unwieldy plays were in fact subjected at the time was in keeping with Voltairean principles. And A. W. 
Schlegel's romantic Shakespeare criticism, which coincided with that in Coleridge's Lectures, was of course ultimately designed to establish the universality, not the nationality of Shakespeare's autonomous, organic and ironic art. Nor was the anti-French stance of much of the early Shakespeare discourse - for which Voltaire was employed as a scapegoat once he had disseminated more critical views in his Lettre à l'Académie - peculiar to Germany. Clearly it was shared and indeed anticipated in England ${ }^{7}$, since both England and Germany had reason to react to the tyranny of French influence in terms of both culture and - especially at the time of Napoleon - politics.

In post-Napoleonic Germany Shakespeare himself was by some authors felt to be tyrannical. The dramatist C. D. Grabbe, for instance, in 1827 inveighed against what he described as the "Shakespeare mania" and the "despotism" of Shakespeare's excessive admirers. In the reactionary 1830 s, revolutionary poets of the Young Germany movement, including Börne and Heine, poured their hatred on Hamlet in particular to disparage him as a symbol of German political inactivity and disunity: «Germany is Hamlet», began Freiligrath's famous poem to that negative effect. Forty years later, however, in 1877 , once Germany was unified and able to display its strength, the American scholar $\mathrm{H}$. $\mathrm{H}$. Furness decorated his monumental Variorum edition of Hamlet with that grotesquely printed dedication to the German Shakespeare Society, «representative of a people that has proven once and for all that Germany is NOT Hamlet». The imperial German scholars thus addressed appreciated the compliment, hastened to confer upon Furness an honorary doctorate ${ }^{8}$ and went on to devise new interpretations that were to turn Hamlet into a more appropriately heroic figure for Germans to identify themselves with.

Indeed much of the nationalist Shakespeare discourse evolved, from the mid-nineteenth century onwards, in retaliation against those who, while not denying Shakespeare's greatness, remained sceptical about the attention paid to what after all was a foreign author. It was to dispel their doubts that a rhetoric vindicating Shakespeare's German appropriation became conspicuous. It required more than mere evocations of the common Germanic heritage that permitted England and Germany to have their national poet in common. What had to be proved was that adoring, studying and performing Shakespeare in Germany was more truly patriotic than either the xenophobic disparagement or the romantic 
universalization of such enterprises. Hence compelling metaphors invoking nature, law and war derived from political rather than from aesthetic discourse were reiterated with little variation. Germany's right to Shakespeare was declared to be both one of ownership ( «Shakespeare's works have, ever since Herder, been the property of our nation»") and one of conquest ("Certain it is that we have conquered the great poet for ourselves, just as the English have conquered our Händel» ${ }^{10}$ ). The conquest was also attributed to the assiduity and thoroughness of German scholarship. Small wonder that such discourse grew anti-British as well, especially when in 1864 - at a time when England was blamed for supporting Germany's enemies in the war over Schleswig-Holstein - the foundation of the Deutsches Shakespeare Gesellschaft provided it with a public forum. Professor Ulrici, who presided one of the first meetings of that body, proclaimed what at that time was to be one of its major objectives: "We want to de-Anglicise the Englishman Shakespeare, to Germanize him in the widest and deepest sense of the word» ${ }^{11}$. Around 1900 it became customary to underpin that de-Anglicisation with pseudo-historical arguments. While Shakespeare (so they ran) had been neglected, misunderstood and betrayed by his own countrymen - first by the Puritans, later by materialist liberals - current conditions in Germany were more akin to those of Elizabethan England and closer to Shakespeare's ethical and political ideals. Nazi Propagandists used the same argument with reference to the "renewal" of Germany proclaimed in $1933^{12}$.

And yet one should not be deceived by pronouncements of this kind. It is easy to cull them from Shakespeare books produced in large quantities, and also from the early volumes of the Shakespeare Gesellschaft's Jahrbuch. But seen in a larger context their apologetic nature is demonstrable. For the nationalist appropriation of Shakespeare had in many ways been counteracted and subverted throughout the nineteenth-century - by a romantic interest in irony and illusion, by authors in defence of their independent creativity or in quest of realist drama, or by those pleading for a neo-classicist renewal of the German theatre. Even the Schlegel-Tieck translation canonized in 1901 (doubtless because it sounded like German classic drama of the Goethe era) had in fact been challenged and confronted with alternatives through the nineteenth century. At the very moment when Professor Brandl declared it to be unsurpassable, F. Gundolf began 
to work on his new translation of the complete works inspired by the poetry of Stefan George. In the twentieth century many more Shakespeare translators have been active, whose efforts revealed theatrical energies of Shakespeare's text that Schlegel had neglected, and who provided either more modern or more baroque, more actable or more readable equivalents. The wealth of creative insight and critical imagination contained in the sheer quantity of these translations may well testify to an involvement beyond mere national interests.

Shakespeare's national appropriaiton was subverted even more thoroughly by the activities and energies of the theatre. It is true that tragedies such as Hamlet and also the Histories, on which intellectual patriotism dwelt with especial emphasis, were frequently performed as well. But nineteenth-century actors were perfectly capable of contributing an experience and a sensitivity of their own. Besides, the theatre also favoured the comedies, which at that time were relatively unmolested by ideological preoccupation. It is perhaps no coincidence that the first two Shakespeare translators of note, C. M. Wieland and A. W. Schlegel, both approached their task by first rendering A Midsummer Night's Dream, and that Ludwig Tieck, on the basis of $A$ Midsummer Night's Dream and The Tempest, explored Shakespeare's dramatic illusion that ironically replaces the reality on which it depends. When Tieck's involvement with the Dream culminated in his Berlin production of the comedy (1843), that first "unadapted" performance almost coincided with the comparable effort by Elizabeth Vestris and Charles Mathews in London. Mendelssohn's music, which added to its charm, became an almost regular feature of Midsummer Night's Dream productions in Germany and elsewhere. When in 1905 Max Reinhardt exploited the techniques of realist theatre to create the fantastic illusion, he was undercutting the German Shakespeare myth at the very time its cultivation had reached its most dogmatic stage, and his thirteen subsequent productions of the play included one in the park of the Palazzo Pitti in Florence as well as the Hollywood film. Between the World Wars, the Dream was no less central to Otto Falckenberg's theatre work in Munich, whose four productions progressively revealed «a dangerous play with the power of the darkness of human nature ${ }^{13}$, a revelation that was assisted by $R$. A. Schröder's robust new translation and by the replacement of Mendelssohn's musical harmony by the dissonances of Carl Orff. Progressive 
post-war productions of the Dream anywhere tended to move further in this direction, until in the 1970s Peter Brook's RSC production set a new standard, by which hardly any German production remained unaffected for at least a decade. This occurred when, in the early 1970s, the iconoclastic treatment of Shakespeare and other classics was well under way, when Shakespeare performances were made to release a free play of fragmentation and association, when Jan Kott was a major influence, when Shakespeare's performances were inspired by Japanese theatre traditions (in German and English productions as well as in A. Mnouchkine's French ones), etc. None of this required a specifically German approach. It is true that, even so, the print media have not ceased to promulgate articles entitled "Shakespeare in Germany" or "Germany is Hamlet" or "Germany is NOT Hamlet"14. But surely the insular notion of Unser Shakespeare has by now been absorbed by the international cross-currents of Shakespeare reception and production.

Werner HABICHT

Universität Würzburg

\section{NOTES}

1. See Shakespeare Jahrbuch 37 (1901), pp. xxxv-lv, esp. p. xliii.

2. Cf. Max Förster, "Shakespeare und Deutschland", Shakespeare Jahrbuch 57 (1921), pp. 7-27.

3. Gerhart Hauptmann, "Deutschland und Shakespeare", Shakespeare Jahrbuch 51 (1915), pp. vii-xii, esp. p. xii.

4. "Shakespeare and the Drama", repr. in Shakespeare in Europe, ed. O. Le Winter (Harmondsworth : Penguin, 1970), p. 264.

5. See particularly Das Shakespeare-Bild zwischen Aufklärung und Romantik, ed. Roger Bauer (Bern etc., 1988).

6. K. E. Larson, "Traditions and New Directions in the Study of French and German Shakespeare Reception", Michigan German Studies 15 (1989), 103-113.

7. For a recent study see Michael Dobson, The Making of the National Poet (Oxford, 1982).

8. See Georgianna Ziegler in Deutsche ShakespeareGesellschaft West, Jahrbuch 1985 (Bochum, 1985), p. 267 ; James 
M. Gibson, The Philadelphia Shakespeare Story (New York, 1990), p. $97 \mathrm{f}$.

9. August Koberstein, Vermischte Aufsätze zur Litteraturgeschichte und Ästhetik (Leipzig, 1858), p. 21.

10. G. G. Gervinus, Shakespeare (Leipzig, 1849-50; 4th edn. 1872), vol. I, p. viii.

11. Hermann Ulrici in Shakespeare Jahrbuch 24 (1867), 3.

12. See Werner Habicht, "Shakespeare and Theatre Politics in the Third Reich", in The Play out of Context, ed. H. Scolnicov and P. Holland (Cambridge, 1989), pp. 112-120.

13. Otto Falckenberg, "Zur Frage der Inszenierung des Sommernachtstraums", Shakespeare Jahrbuch 77 (1941), p. 120.

14. Cf. Manfred Pfister, "Hamlet und der deutsche Geist : Die Geschichte einer politischen Interpretation", Deutsche ShakespeareGesellschaft West, Jahrbuch 1992 (Bochum, 1992), pp. 13-38. 